\title{
Selection of Cowpea Lines for Multiple Traits by GYT Biplot Analysis
}

\author{
Derivaldo Pureza da Cruz (Corresponding Author)
}

PhD Student in Genetics and Plant Breeding, North Fluminense State University Darcy

Ribeiro, Center for Agricultural Science and Technology, Alberto Lamego Ave, 2,000, BR

281013-602, Campos dos Goytacazes, RJ, Brazil. E-mail: deri.engineer@gmail.com

\section{Tâmara Rebecca Albuquerque de Oliveira}

PhD in Genetics and Plant Breeding, North Fluminense State University Darcy Ribeiro, Center for Agricultural Science and Technology, Alberto Lamego Ave, 2,000, BR 281013-602, Campos dos Goytacazes, RJ, Brazil.E-mail: tamara_rebecca@hotmail.com

\section{Andréa Barros Silva Gomes}

PhD in Genetics and Plant Breeding, North Fluminense State University Darcy Ribeiro, Center for Agricultural Science and Technology, Alberto Lamego Ave, 2,000, BR 281013-602, Campos dos Goytacazes, RJ, Brazil. E-mail: andreabsgomes@gmail.com

\section{Camila Queiroz da Silva Sanfim de Sant'Anna}

Doctor in Plant Production, North Fluminense State University Darcy Ribeiro, Center for Agricultural Science and Technology, Alberto Lamego Ave, 2,000, BR 281013-602, Campos dos Goytacazes, RJ, Brazil. E-mail: mylacqs@gmail.com

\section{Lília Marques Gravina}

Doctor in Plant Production, North Fluminense State University Darcy Ribeiro, Center for Agricultural Science and Technology, Alberto Lamego Ave, 2,000, BR 281013-602, Campos dos Goytacazes, RJ, Brazil. E-mail: liliagravina@yahoo.com.br

\section{Richardson Sales Rocha}

Master student in Plant Production, North Fluminense State University Darcy Ribeiro, Center for Agricultural Science and Technology, Alberto Lamego Ave, 2,000, BR 281013-602, Campos dos Goytacazes, RJ, Brazil.E-mail: richardson_sales@hotmail.com 
Mário Euclides Pechara da Costa Jaeggi

PhD Student in Plant Production, North Fluminense State University Darcy Ribeiro, Center for Agricultural Science and Technology, Alberto Lamego Ave, 2,000, BR 281013-602,

Campos dos Goytacazes, RJ, Brazil. E-mail: mariopechara@hotmail.com

\section{Israel Martins Pereira}

PhD Student in Plant Production, North Fluminense State University Darcy Ribeiro, Center for Agricultural Science and Technology, Alberto Lamego Ave, 2,000, BR 281013-602,

Campos dos Goytacazes, RJ, Brazil. E-mail: israelmartins80@gmail.com

\section{Geovana Cremonini Entringer}

$\mathrm{PhD}$ in Genetics and Plant Breeding, North Fluminense State University Darcy Ribeiro, Center for Agricultural Science and Technology, Alberto Lamego Ave, 2,000, BR 281013-602, Campos dos Goytacazes, RJ, Brazil. E-mail: geovanaentringer@gmail.com

\section{Geraldo de Amaral Gravina}

Professor Doctor, North Fluminense State University Darcy Ribeiro, Center for Agricultural Science and Technology, Alberto Lamego Ave, 2,000, BR 281013-602, Campos dos Goytacazes, RJ, Brazil. E-mail: gravina@uenf.br

\section{Marcelo Vivas}

Professor Doctor, North Fluminense State University Darcy Ribeiro, Center for Agricultural Science and Technology, Alberto Lamego Ave, 2,000, BR 281013-602, Campos dos Goytacazes, RJ, Brazil. E-mail: mrclvivas@hotmail.com

\section{Rogério Figueiredo Daher}

Professor Doctor, North Fluminense State University Darcy Ribeiro, Center for Agricultural Science and Technology, Alberto Lamego Ave, 2,000, BR 281013-602, Campos dos

Goytacazes, RJ, Brazil. E-mail: rogdaher@uenf.br

Received: Oct. 16, 2019

doi:10.5296/jas.v8i2.16003
Accepted: Nov. 20, 2019 Published: Dec. 8, 2019

URL: https://doi.org/10.5296/jas.v8i2.16003 


\section{Abstract}

Cowpea is an African legume that was introduced to Brazil by Portuguese settlers in the mid-16th century. The productive potential of this crop may fluctuate depending on its environment. The objective of the present study was to select cowpea lines with high grain yield coupled with other traits of agronomic interest, such as good adaptability and stability, by the GYT biplot methodology. Twelve lines were evaluated in the years 2016 and 2017 in the municipality of Bom Jesus de Itabapoana, Brazil, in a randomized-block design with four replicates and two cultivars, which were used as controls. The following variables were evaluated: number of days to flowering, final stand, crop value, lodging, pod weight, pod length, seed number per pod, seed weight per pod, 100-seed weight (100SW), and grain yield. Analysis of variance was performed and GYT biplots were constructed using R software and the ggplot2 package. The GYT biplot graph analysis allowed for the selection of superior cowpea genotypes. In the combinations of traits observed, lines L1, L3, L5, L6, L8, and L9 were superior and cultivar Imponente stood out as one of the controls. The yield combinations $\mathrm{GY} * \mathrm{CV}, \mathrm{GY} * \mathrm{NDF}, \mathrm{GY}{ }^{*} \mathrm{LDG}, \mathrm{GY} * \mathrm{CV}, \mathrm{GY} * \mathrm{PW}, \mathrm{GY} * \mathrm{SNP}$ and GY*P100G were positively correlated with each other but showed negative to highly negative correlations with GY*SWP and GY*TS.

Keywords: Vigna unguiculata (L.) Walp., multivariate analysis, yield, autogamous

\section{Introduction}

Vigna unguiculata (L.) Walp. is an African legume that was introduced to Brazil by Portuguese settlers in the state of Bahia, in the mid-16th century. Despite having been established mainly in the North and Northeast regions of Brazil due to subsistence production, the cowpea crop has gained prominence in the Brazilian agricultural scene (Freire Filho, 2011).

According to the National Supply Company (CONAB, 2019), the average yield of cowpeas in Brazil is estimated at $535 \mathrm{~kg} / \mathrm{ha}$, with the Central-West, Central-South, Southeast, and Northeast regions representing the largest shares of this total. Because cowpeas are grown in different environments, it is difficult to obtain high-yield cultivars that possess other traits of agronomic and market interest.

Crop yield, along with other secondary traits of interest, requires analysis techniques that allow for a better understanding of the associations and correlations between traits inserted in a highly complex biological system (Yan \& Rajcan, 2002). As stated by Paramesh et al. (2016), some statistical analyses make it possible to study the correlations between traits.

When the objective is to describe only the correlation between two variables, simple correlation suffices. However, when working with many variables, multivariate analysis is required. Previous studies have used multivariate analyses to compare different crops (Atnaf et al. 2017; Farid et al. 2017; Mathobo \& Marais, 2017), and some of its advantages include being able to compare all data variables with one statistical test and being able to easily interpret the data. 


\section{Macrothink}

Journal of Agricultural Studies

ISSN 2166-0379

2020, Vol. 8, No. 2

The genotype by yield by trait (GYT) biplot analysis is based on the combined phenotypic means of these variables, in accordance with the methodology proposed by Yan \& Frégeau-Reid (2018). This approach consists of generating high values by multiplying the mean of a trait by the yield (e.g., SNP*GY), or by dividing the mean by the yield, when aiming for lower values (e.g., GY/NDF). In this way, the yield will be part of all combinations with the traits discriminated in the biplot.

This analysis stands out among multivariate methodologies in that it evaluates genotypes based on multiple traits, providing a more effective process for the selection of superior genotypes based on combinations between yield and other traits of interest. The selected genotypes can be used as parents in breeding programs or possible commercial cultivars.

In addition, this analysis allows a quick and practical visualization of the genetic correlation between traits. This allows the plant breeder to discard minor variables, make occasional changes to the breeding process, and indirectly select superior individuals, which saves resources and time in the obtaining the final product of the breeding program (Mohammadi \& Amri, 2013).

In this study, we aimed to select cowpea lines for multiple traits based on GYT biplot analyses.

\section{Materials and Methods}

\subsection{Genetic Material Used and Installation of the Experiment}

This experiment was established in 2016 and 2017 at the Federal Fluminense Institute, located in Cambuci - RJ, Brazil ( $21^{\circ} 08^{\prime} 02^{\prime \prime S}, 41^{\circ} 40^{\prime} 47^{\prime \prime} \mathrm{W} ; 88 \mathrm{~m}$ altitude), where the climate is tropical, according to the Köppen-Geiger climatic classification (Alvares et al. 2013), with an average annual temperature of $23{ }^{\circ} \mathrm{C}$. The soil is classified as Red-Yellow Latosol + Cambisol type. Fourteen cowpea genotypes of the 'cores' commercial group were evaluated in this study, using cultivars BRS Tumucumaque and BRS Imponente as controls (Table 1). 
Table 1. Identification of 14 cowpea genotypes evaluated in the municipality of Cambuci - RJ, Brazil, 2016/2017

\begin{tabular}{|c|c|c|}
\hline $\mathrm{N}$ & Line code & Commercial subclass ${ }^{(1)}$ \\
\hline 01 & Bico-de-ouro 1-5-11 & SV \\
\hline 02 & Bico-de-ouro 1-5-15 & SV \\
\hline 03 & Bico-de-ouro 1-5-19 & SV \\
\hline 04 & Bico-de-ouro 1-5-24 & ML \\
\hline 05 & Pingo-de-ouro 1-5-26 & ML \\
\hline 06 & Pingo-de-ouro 1-5-4 & ML \\
\hline 07 & Pingo-de-ouro 1-5-5 & ML \\
\hline 08 & Pingo-de-ouro 1-5-7 & ML \\
\hline 09 & Pingo-de-ouro 1-5-8 & ML \\
\hline 10 & Pingo-de-ouro 1-5-10 & ML \\
\hline 11 & Pingo-de-ouro 1-5-11 & ML \\
\hline 12 & Pingo-de-ouro 1-5-14 & ML \\
\hline 13 & BRS Tumucumaque & $\mathrm{BR}$ \\
\hline 14 & BRS Imponente & $\mathrm{BC}$ \\
\hline
\end{tabular}

(1) BR- Branco; BC - Brancão; ML- Mulato; SV- Sempre-verde

In this study, the cowpea commercial subclass is indicative of the genetic variability within Vigna unguiculata species. Its importance is linked to consumer preference in each growing region (Freire Filho, 2011).

\subsection{Statistical Design Used}

A randomized complete block design with four replications was used in this study. The experimental plots consisted of four $5 \mathrm{~m}$ long lines spaced $0.50 \mathrm{~m}$ apart. The usable area consisted of the two central lines of each plot, eliminating $0.5 \mathrm{~m}$ from each end, totaling $4 \mathrm{~m}^{2}$ of usable area. Twelve seeds were sown per linear meter. After emergence, plants were 
thinned, leaving ten plants per meter. The soil was prepared by the conventional method, with one tillage and two pre-sowing harrows. Subsequently, the area was furrowed and fertilized using a mechanized seed drill. Sowing was carried out with the help of hand sowing machines. Fertilization was performed according to the nutritional requirements of cowpea crops (Melo et al. 2005). Thus, $20 \mathrm{~kg} \mathrm{ha}^{-1}$ of $\mathrm{K}_{2} \mathrm{O}$ and $20 \mathrm{~kg} \mathrm{ha}^{-1}$ of $\mathrm{P}_{2} \mathrm{O}_{5}$ were applied to the sowing, and $20 \mathrm{~kg} \mathrm{ha}^{-1}$ of $\mathrm{N}$ in coverage. Supplementary irrigation was used in conventional sprinkler tests from sowing to pod maturation. Harvesting was performed manually during physiological maturation and pods of each genotype were then dried.

\subsection{Variables Analyzed}

The following variables were evaluated: number of days to flowering (NDF): determined by counting the days from emergence to the production of the first flower; final stand (FS): determined by counting the number of fully developed plants; crop value (CV): measured by a visual assessment of the plant; lodging (LDG): determined by counting the number of lodged plants; pod weight (PW): obtained using a precision scale, in grams (g); pod length $(\mathrm{PL})$ : measured with a graduated ruler, in centimeters $(\mathrm{cm})$; seed number per pod (SNP): determined by counting the seeds; seed weight per pod (SWP): obtained using a precision scale, in grams (g); 100-seed weight (100SW): obtained using a precision scale, in grams (g); and grain yield (GY): obtained using a precision scale, in grams $(\mathrm{g})$.

\subsection{Genetic-Statistical Analysis}

To construct the biplots, the principal component 1 (PC1) was used on the horizontal axis and principal component 2 (PC2) on the vertical axis, based on singular-value decomposition (SVD), according to the equation proposed by Yan \& Frégeau-Reid 2018):

$$
P_{i j}=\left(\mathrm{d} \lambda_{1}^{\alpha} \xi_{i 1}\right)\left(\frac{\lambda_{1}^{1-\alpha} \tau_{1 j}}{d}\right)+\left(\mathrm{d} \lambda_{2}^{\alpha} \xi_{i 2}\right)\left(\frac{\lambda_{2}^{1-\alpha} \tau_{2 j}}{d}\right)+\varepsilon_{i j}
$$

Where $\xi_{i 1}$ and $\xi_{i 2}$ are eigenvalues for the first and second principal components, respectively, in genotype $\mathrm{i} ; \tau_{1 j}$ and $\tau_{2 j}$ are eigenvalues for the first and second principal components, respectively, in trait $\mathrm{j} ; \lambda_{1}$ and $\lambda_{2}$ represent the eigenvalues for the first and second principal components, respectively; $\alpha$ is the singular partitioning value factor; and $\varepsilon_{i j}$ is the residue of the two principal components of genotype $\mathrm{i}$, combined with yield trait $\mathrm{j}$.

The R software and the ggplot2 package (R Development Core Team, 2014) were used for the analysis of variance and construction of the graphs.

\section{Result and Discussion}

\subsection{Average Squares of Characteristics}

There was a significant difference between the genotypes for FS, CV, LDG, PL, SNP, and $100 \mathrm{SW}$, indicating the existence of genetic variability between lines and thence the possibility 
of selecting superior lines for the studied traits. Our analysis also revealed significant differences for the line $\times$ year interaction, with changes in production performance existing in the lines between years (Table 2).

Table 2. Mean squares of the lines for number of days to flowering (NDF), final stand (FS), crop value (CV), lodging (LDG), pod weight (PW), pod length (PL), seed number per pod (NSP), seed weight per pod (SWP), 100-seed weight (100SW), and grain yield (GY)

\begin{tabular}{|c|c|c|c|c|c|c|c|c|c|c|c|}
\hline \multirow{2}{*}{ VS } & \multirow{2}{*}{ DF } & \multicolumn{10}{|l|}{ MS } \\
\hline & & $\mathrm{NDF}$ & FS & $\mathrm{CV}$ & LDG & PW & PL & SNP & SWP & $100 \mathrm{SW}$ & GY \\
\hline $\begin{array}{l}\text { Block } \\
\text { (year) }\end{array}$ & 6 & 786.97 & 71.46 & 0.30 & 0.82 & 23.65 & 0.44 & 12.24 & 47.93 & 9.72 & 3.12 \\
\hline Year & 1 & $7772.22 * *$ & $39637.94 * *$ & $8.04 * *$ & 0.32 & $1579.01 * *$ & $71.04 * *$ & $157.70 * *$ & $942.50 * *$ & $1467.40 * *$ & $20.47 *$ \\
\hline Lines & 13 & 160.74 & $182.00 * *$ & $1.14 * *$ & $1.30 * *$ & 2.70 & $2.54 * *$ & $9.80 * *$ & 37.75 & $70.43^{* *}$ & 3.36 \\
\hline $\begin{array}{l}\text { Lines } \times \\
\text { year }\end{array}$ & 13 & 241.30 & $114.99 *$ & 0.46 & 1.51 & 10.93 & 1.68 & 3.20 & 28.51 & $27.12 * *$ & 3.37 \\
\hline Error & 78 & 287.38 & 59.50 & 0.30 & 0.40 & 6.73 & 0.92 & 2.92 & 40.94 & 5.47 & 3.38 \\
\hline
\end{tabular}

$*$ and $* *$ indicates significance at the $5 \%$ and $1 \%$ levels, respectively.

The significance of the lineage $\times$ year interaction allowed us to infer that there was a direct influence on the performance of two of the analyzed variables, FS and 100SW. Such behavior calls for the continuation of interaction investigations, given the possibility of expressing its complex nature, making it difficult to recommend superior genotypes in the tested environments (Cruz \& Castoldi, 1991). According to the authors, the interaction may be simple in nature, originating from the difference in the genetic variability between strains in a particular environment, or complex, attributed to the absence of correlation between the strains under study.

\subsection{Biplot GYT Representing the "Who Won Where" and Feature Group Formation}

In the GYT biplot analysis, the first two PCs explained $94.41 \%$ of the existing variation between the lines (Figure 1). The observed difference in performance between the lines justifies the need for examining their behavior in order to select those which carry agronomic traits of interest as well as good grain yield. 


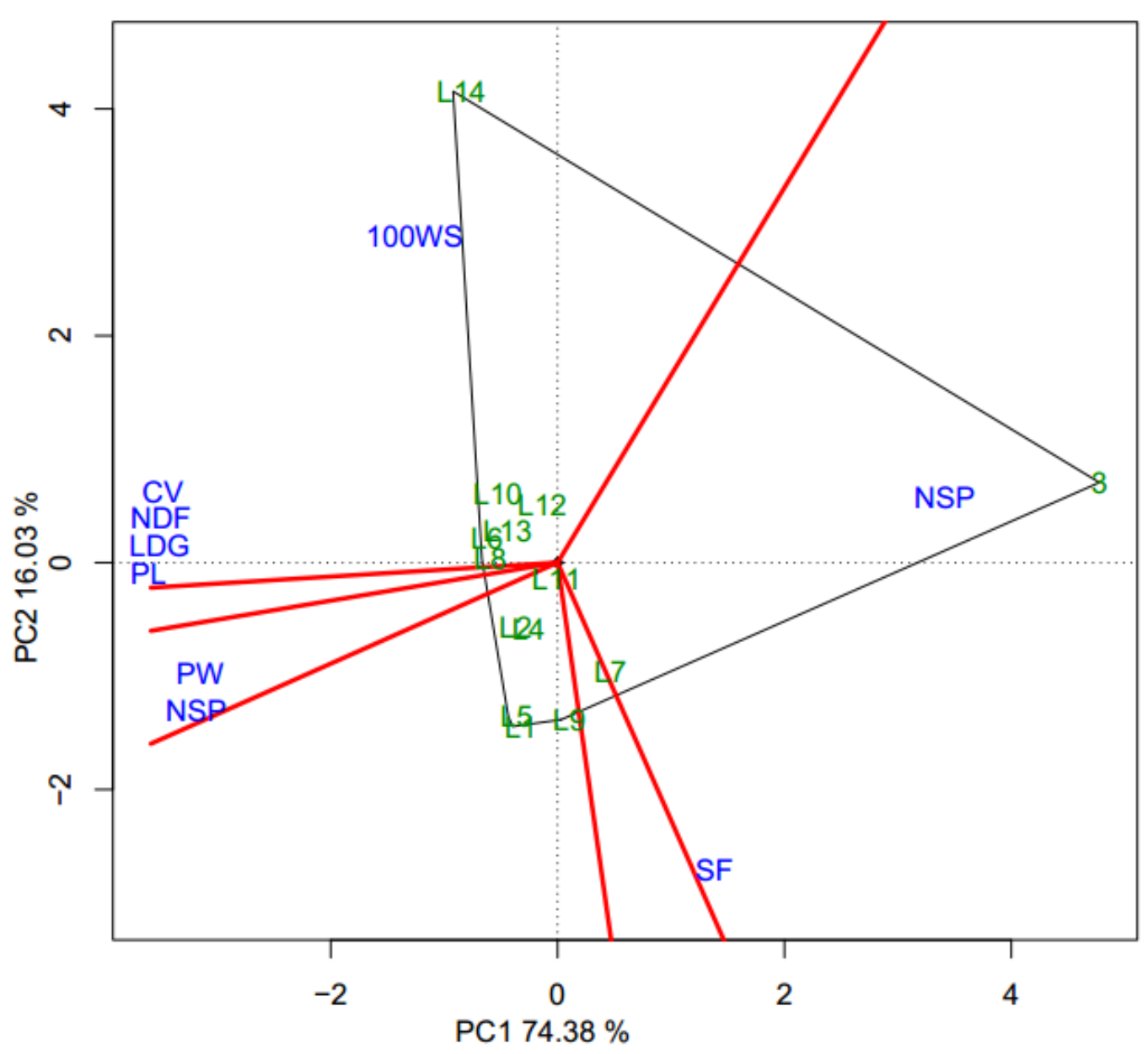

Figure 1. GYT biplot representing the "which-won-where" of 14 cowpea genotypes. The results are the combinations between grain yield (GY) and number of days to flowering (NDF), final stand (FS), crop value (CV), lodging (LDG), pod weight (PW), pod length (PL), seed number per pod (NSP), seed weight per pod (SWP), and 100-seed weight (100SW)

Principal Component Analysis is a multivariate statistical technique that aims to transform a set of original variables into a set of variables of the same dimension called principal components. Some important properties of the main components are: (1) each main component is a linear combination of all original variables; (2) they are independent of each other; and (3) they are intended to retain the maximum amount of information regarding the total variation contained in the data (Johnson \& Wichern, 1998; Hongyu, 2015).

According to Yang et al. (2009), high percentages of representativeness of the main components considered demonstrate the reliability of the data analyzed and the applicability of the methodology, thus allowing better discrimination of the variables. By this approach, 
the best lines will not be selected based on individual traits, but rather a combination between GY and a secondary trait of agronomic interest (Yan \& Frégeau-Reid, 2018).

The highest-yielding lines are selected based on their location in the irregular polygon within the GYT biplot. In this way, lines located at the polygon vertices are superior for the sets of yield-related traits allocated in their respective groups. Otherwise, those located within the polygon are classified as having inferior performance (Yan, 2001). Five groups were thus formed: the first (G1) consisted of the GY*SWP combination. Plant stand constituted the second group (G2), represented by GY*FS. The third group (G3) contained two combinations related to pod yield: GY*PW and GY*SNP.

Group four (G4) included the largest number of combinations, namely, GY*PL, GY*LDG, $\mathrm{GY}^{*} \mathrm{NDF}$, and $\mathrm{GY} * \mathrm{CV}$. Group five (G5), in turn, was formed only by the combination GY*100SW, where the second characteristic is one of the main components of GY, considering that cowpea is a dual purpose crop (i.e., it can be grown both for the production of pods and for obtaining dry grains).

Line L3 was placed at the vertex of the first group, indicating that it was superior in the combination between GY and SWP. Lines L9 and L7 stood out in group G2. Moreover, in group G3, lines L1 and L5 showed superior performance for the combinations GY and PW and NSP. In the formation of G4, lines L6 and L8 stood out as superior performers based on phenological traits. Line 14 was superior in its position at the vertex, relating yield to $100 \mathrm{SW}$. 


\subsection{GYT Biplot Means $\times$ Characteristics}

The superior lines were classified based on singular-value partitioning and their combinations of yield-related traits (Figure 2).

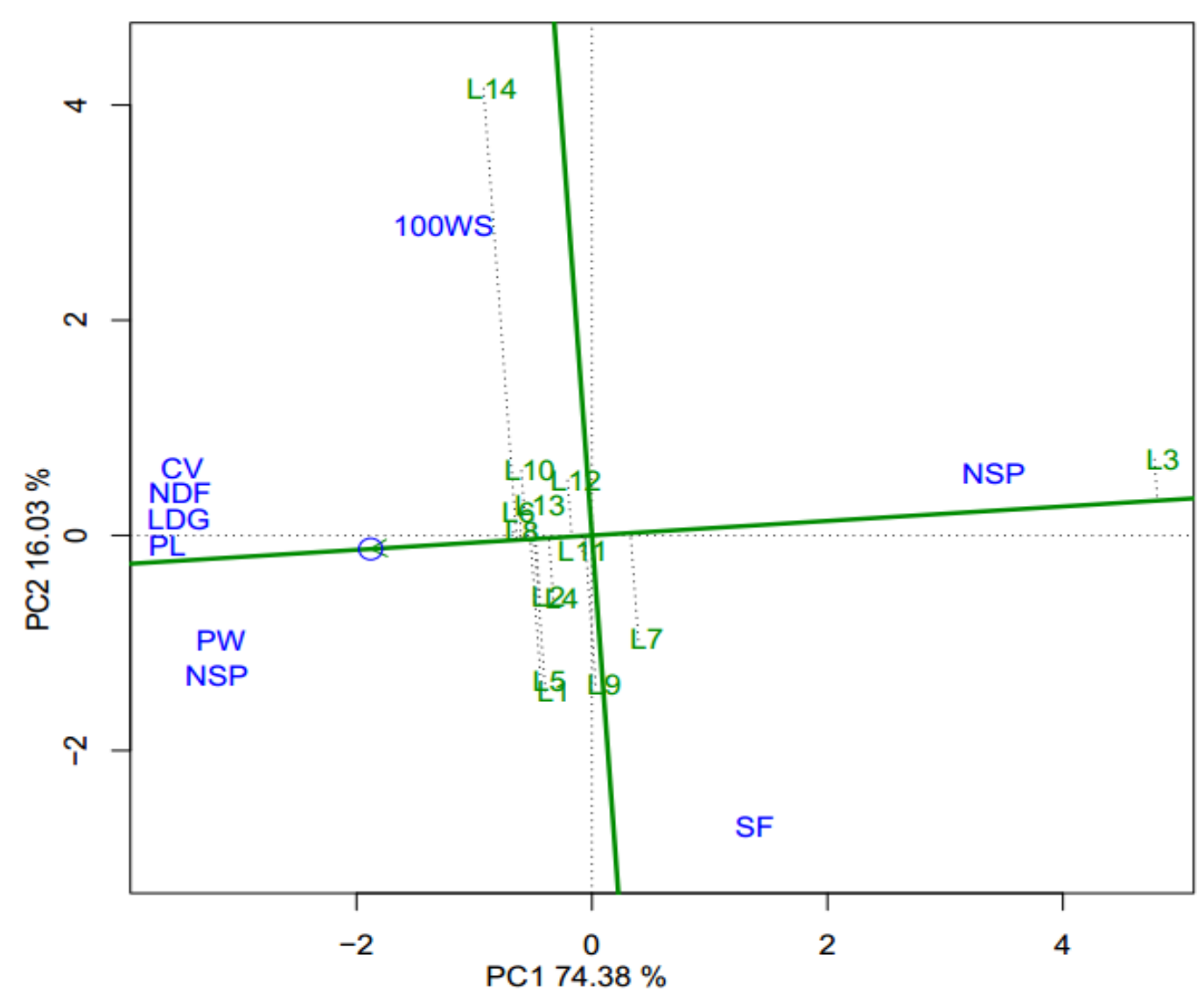

Figure 2. GYT biplot representing means $\times$ traits, displaying the rank of 14 lines of cowpea for the 10 evaluated traits. The results are the combinations between grain yield (GY) and number of days to flowering (NDF), final stand (FS), crop value (CV), lodging (LDG), pod weight (PW), pod length (PL), seed number per pod (NSP), seed weight per pod (SWP), 100-seed weight (100SW)

The length of the vector, which comprises the distance to the origin of a feature's biplot, indicates how well the feature is represented by the biplot. Relatively short vectors indicate that the variation in the trait between genotypes is small, or that it is not well presented in the biplot due to the low magnitude or lack of correlation with other traits, or when biplot adjustment is of inferior quality (Yan \& Frégeau-Reid, 2018).

The circle formed on one of the coordinates of the biplot indicates the average position of the combinations of yield-related traits. The vertical line separates the genotypes according to the means, with the genotypes situated on the right side (i.e., the same side as the 


\section{Macrothink}

average tester axis (ATA)) having a superior average performance for combinations between yield-related traits (Yan \& Frégeau-Reid, 2018).

According to Yan \& Frégeau-Reid (2018), the length of the projection formed in the direction of ATA determines the discriminatory power, with the lines presenting smaller projections tending to encompass a balanced set of yield-related traits, whereas larger projections are more discriminatory for certain combinations. None of the lines presented a performance superior to the general average of the tests, delimited by the circle ATA. However, lines L1, L2, L4, L5, L6, L8, L9, L10, L11, L12, L13, and L14 showed yields within the overall average, and only lines L3 and L7 showed lower than average GY performance.

\subsection{Correlation Between Characteristics}

The analysis of correlations between combinations of characteristics is presented in Figure 3.

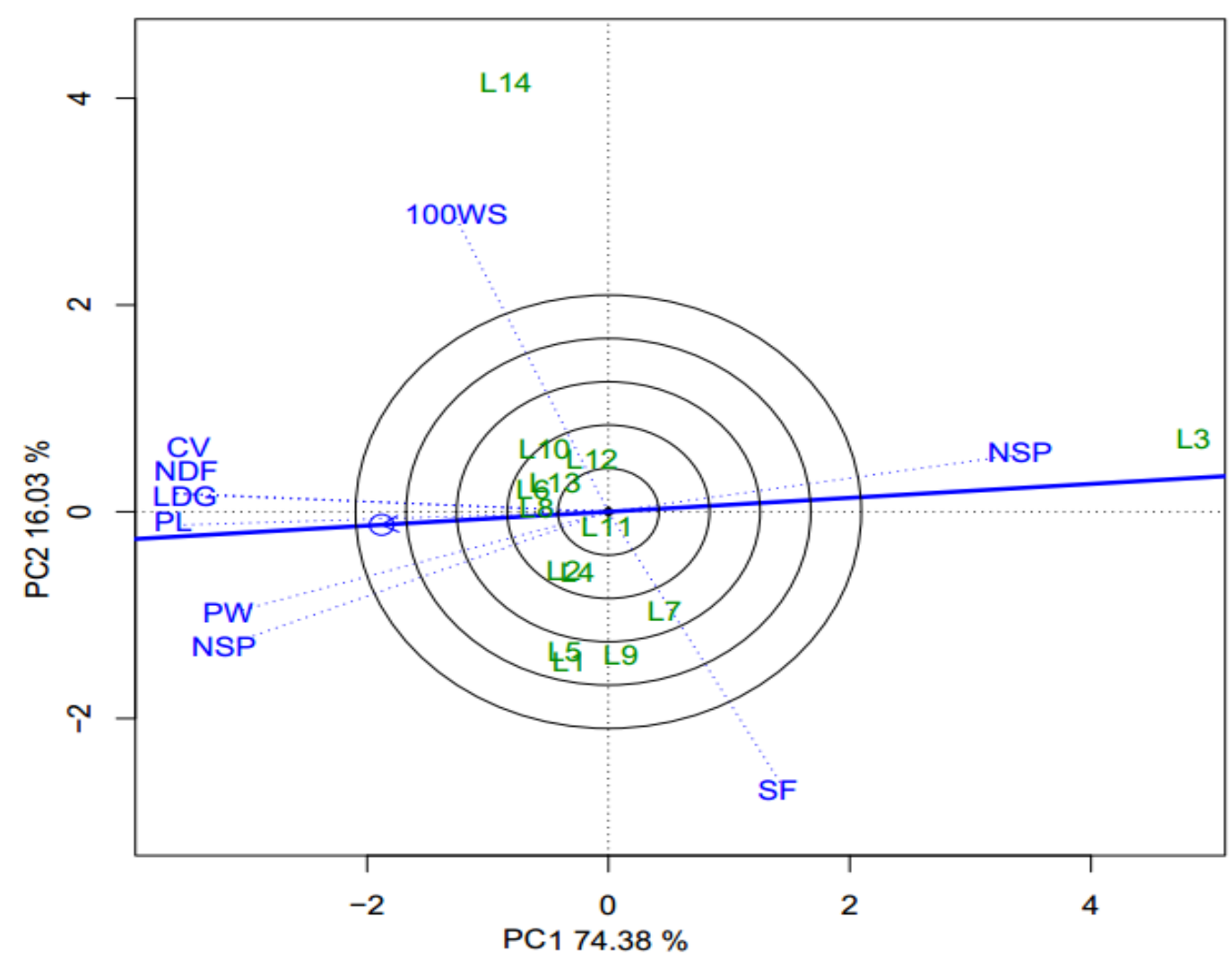

Figure 3. GYT biplot that discriminates which of the 14 cowpea genotypes were superior for each trait. Grain yield (GY) is in combination with number of days

to flowering (NDF), final stand (FS), crop value (CV), lodging (LDG), pod weight (PW), pod length (PL), seed number per pod (NSP), seed weight per pod

(SWP), 100-seed weight (100SW) 
To determine the magnitude of the existing correlation between two sets of yield-related variables, acute angles $\left(<90^{\circ}\right)$ were considered indicative of positive correlations, whereas right angles $\left(=90^{\circ}\right)$ were indicative of variables that were not correlated. Lastly, obtuse angles $\left(>90^{\circ}\right)$ reveal negative correlations, and vectors forming $180^{\circ}$ angles indicate the existence of traits that are highly negatively correlated (Oliveira et al. 2018).

Yan et al. (2007) indicated that the ideal environment should be highly discriminating with respect to the evaluated, and at the same time representative, geotypes. The representativeness of the environment is inferred by the angle formed between the vector environment and the abscissa of the medium axis of the environment. So, the larger the angle, the more representative the environment.

The combinations $\mathrm{GY}^{*} \mathrm{CV}, \mathrm{GY} * \mathrm{NDF}, \mathrm{GY}{ }^{*} \mathrm{LDG}$, and GY*PL were positively correlated with each other and with GY*PW, GY*SNP and GY*100SW. This shows that as line selection is practiced upon one of those combinations, gains can be obtained for other traits. However, this set of combinations showed negative to highly negative correlations with GY*SWP and GY*TS, indicating that the gain obtained with the selection of one of the combinations would lead to a reduction in gains for those variables.

Mambrin et al. (2015) observed a high-magnitude positive correlation between GY characteristics and the number of days from emergence to flowering $(r=0.77)$. However, Cabral et al. (2011) evaluated 58 bean strains in an experiment carried out in Espírito Santo and found that GY and number of days for flowering presented a negative correlation of moderate magnitude $(r=-0.52)$. For Zilio et al. (2011), the magnitude of these correlations may vary depending on the genetic diversity of the evaluated germplasm.

As can also be seen in the figure 3, there was no correlation between the combinations GY*PW and GY*SNP with GY*100SW and GY*TS, respectively, whereas GY*100SW was very negatively correlated with GY*TS. Thus, alterations of values between the traits of the selected lines would be conditioned to the occurrence of correlations of significant magnitudes.

Andrade et al. (2010) stated that it is very important to determine the correlations between traits because of their influence on the selection process, since significant gains can be obtained in individual selection due to the high expression of the genetic and phenotypic component. In this study, the authors evaluated cowpea genotypes focusing on fresh-seed yield and the observed negative and positive correlations between many of the evaluated traits.

\section{Conclusions}

The GYT biplot methodology allowed us to select cowpea lines of superior performance, focusing on combinations between yield and other traits of interest, with easily interpreted results. When considering the sets of combinations of traits observed in this study, lines L1, L3, L5, L6, L8, L9, and cultivar Imponente were superior. The majority of the evaluated traits were positively correlated for these genotypes. 


\section{Acknowledgements}

We thank the Coordination of Improvement of Higher Education Personnel (CAPES) for the financial support and the North Fluminense State University Darcy Ribeiro for the support and logistics provided to the research.

\section{References}

Alvares, C. A., Stape, J. L., Sentelhas, P. C., Moraes, G., Leonardo, J., \& Sparovek, G. (2013). Köppen's climate classification map for Brazil. Meteorologische Zeitschrift, 22(6), 711-728. https://doi.org/10.1127/0941-2948/2013/0507

Andrade, F. A., Rocha, M. M., Gomes, R. L. F., Feire Filho, F. R., \& Ramos, S. R. R. (2010). Estimativas de parâmetros genéticos em genótipos de feijão-caupi avaliados para feijão fresco. Revista Ciência Agronômica, 41(2), 253-258. https://doi.org/10.1590/S1806-66902010000200012

Atnaf, M., Tesfaye, K., Dagne, K., \& Wegary, D. (2017). Genótipo por análise traço biplot para estudar associações e perfis de raças lupinas brancas etíopes ('Lupinus albus' L.). Aust. J. Crop Sci., 11(1), 55-62. https://doi.org/10.21475/ajcs.2017.11.01.pne226

Cabral, P. D. S., Soares, T. C. B., Lima, A. B. P., Soares, Y. J. B., \& Silva, J. A. (2011). Análise de trilha do rendimento de grãos de feijoeiro (Phaseolus vulgaris L.) e seus componentes. Revista Ciência Agronômica, Fortaleza, 42(1), 132-138.

https://doi.org/10.1590/S1806-66902011000100017

CONAB. (2018). Companhia Nacional de Abastecimento. Acompanhamento da safra brasileira de grãos V.6 - SAFRA 2018/2019 - N.2 - Segundo levantamento |Novembro de 2018. Available at: http://www.conab.gov.br. Acessado em: 05 de março de 2019.

Cruz, C. D., \& Castoldi, F. L. (1991). Decomposição da interação genótipos x ambientes em partes simples e complexa. Revista Ceres, 38(219), 422-430.

Farid, M., Earl, H. J., Pauls, K. P., \& Navabi, A. (2017). Response to selection for improved nitrogen fixation in common bean (Phaseolus vulgaris L.). Euphytica, 213(4), 99. https://doi.org/10.1007/s10681-017-1885-5

Freire Filho, F. R. (2011). Feijão-caupi no Brasil: produção, melhoramento genético, avanços e desafios. Teresina, Embrapa Meio-Norte. p. 84.

Hongyu, K. (2015). Comparação do GGE-biplot ponderado e AMMI-ponderado com outros modelos de interação genótipo $\times$ ambiente. Tese (Doutorado em Estatística e Experimentação Agronômica), ESALQ, p. 155.

Johnson, R. A., \& Wichern, D.W. (1998). Applied multivariate statistical analysis. Madison, Prentice Hall International, p. 816. https://doi.org/10.2307/2533879

Mambrin, R. B., Ribeiro, N. D., Storck, L., Domingues, L. S., \& Barkert, K. A. (2015). Seleção de Linhagens de Feijão (Phaseolus vulgaris L.) Baseada em Caracteres Morfológicos, Fenológicos e de Produção. Revista de Agricultura, 90(2), 141-155. 
Mathobo, R., \& Marais, D. (2017). Avaliação da interação genótipo x ambiente usando GGE-biplot em feijão (Phaseolus vulgaris L.) na província de Limpopo, África do Sul. Aust. J. Crop Sci., 11(5), 506-515. https://doi.org/10.5935/1806-6690.20180030

Melo, F. B., Cardoso, M. J., \& Salviano, A. A. C. (2005). Fertilidade do Solo e Adubação. In: Freire Filho, F. R., Lima, J. A. A., Ribeiro, V. Q. (Eds.) - Feijão-caupi: Avanços tecnológicos. Brasília; Embrapa, 6, 213-228.

Mohammadi, R., \& Amri, A. (2013). Genotype $\times$ environment interaction and genetic improvement for yield and yield stability of rainfed durum wheat in Iran. Euphytica, Wageningen, 192(3), 227-249. https://doi.org/10.1007/s10681-012-0839-1

Oliveira, T. R. A., Gravina, G. A., Oliveira, G. H., Araújo, L. C., Araújo, K. C., Cruz, D. P., ... Daher, R. F. (2018). Multivariate analysis used as a tool to select snap bean (Phaseolus vulgaris L.) genotypes. Aust. J. Crop Sci., 12(1), 67-73.

https://doi.org/10.21475/ajcs.18.12.01.pne661

Paramesh, M., Reddy, D. M., Priya, M. S., Sumathi, P., Sudhakar, P., \& Reddy, K. H. P. (2016). GT biplot analysis for yield and drought related traits in mung bean (Vigna radiata L. Wilczek). Electronic Journal of Plant Breeding, 7(3), 538-543.

https://doi.org/10.5958/0975-928X.2016.00069.7

Yan, W. (2001). GGE biplot - A Windows Application for Graphical Analysis of Multienvironment Trial Data and Other Types of Two-Way Data. Agronomy Journal, 93(5), 1111-1118. https://doi.org/10.2134/agronj2001.9351111x

Yan, W., \& Frégeau-Reid, J. (2018). Genotype by Yield* Trait (GYT) Biplot: a Novel Approach for Genotype Selection based on Multiple Traits. Sci. Rep., 8(1), 1-10.

https://doi.org/10.1038/s41598-018-26688-8

Yan, W., \& Rajcan, I. (2002). Biplot analysis of test sites and trait relations of soybean in Ontario. Crop Sci., 42, 11-20. https://doi.org/10.2135/cropsci2002.1100

Yan, W., Manjit S. K., Baoluo Ma., Sheila W., \& Paul L. C. (2007). GGE biplot vs. AMMI analysis of genotype-by-environment data. Crop Sci., 47(2), 643-653.

https://doi.org/10.2135/cropsci2006.06.0374

Yang, R. C. (2009). Análise biplot da interação genótipo $\times$ ambiente: prossiga com cautela. Crop Sci., 49(5), 1564-1576. https://doi.org/10.2135/cropsci2008.11.0665

Zilio, M., Coelho, C. M. M., Souza, C. A., Santos, J. C. P., \& Miquelluti, D. J. (2011). Contribuição dos componentes de rendimento na produtividade de genótipos crioulos de feijão (Phaseolus vulgaris L.). Revista Ciência Agronômica, 42(2), 429-438.

https://doi.org/10.1590/S1806-66902011000200024

\section{Copyright Disclaimer}

Copyright for this article is retained by the author(s), with first publication rights granted to the journal.

This is an open-access article distributed under the terms and conditions of the Creative Commons Attribution license (http://creativecommons.org/licenses/by/4.0/). 